\title{
Serum immunosuppressive acidic protein in renal cell carcinoma
}

\section{ORIGINAL ARTICLE Annals of Cancer Research and Therapy}

\author{
Tomoaki Fujioka, Koichi Ishikura, Michihiko Hasegawa, Naoto Yoshiba, Yasushi Matusita, \\ Masatugu Sato, Yasuki Goto, Kunio Nomura, Susumu Tanji, Tomoshi Okamoto, Takashi Kubo*
}

No useful tumor makers for renal cell carcinoma (RCC) have yet been established. In the present study, the serum IAP level was assessed sa a diagnostic and follow-up marker for RCC. The subject were 16 women and 52 men with RCC ( $28 \sim 87$ years old) and 30 healthy adult controls ( $20 \sim 68$ years old).

Serum IAP levels were assayed by the single radial immunodiffusion method and the cut-off level was set at $500 \mu \mathrm{g} / \mathrm{ml}$. The IAP level was significantly higher in the RCC than in the controls. The IAP positivity rate was $63.2 \%$ in the RCC patients Patients and $16.7 \%$ in the controls. Elevation of IAP was related to clinical stage. The IAP Positivity rate was $83.9 \%$ in patients with high stage RCC and $35.1 \%$ in those with low stage RCC. The prognosis of low stage RCC with IAP level over $1,000 \mu \mathrm{g} / \mathrm{ml}$ was quite poor. In contrast, even high stage patients with IAP levels of $500 \mu \mathrm{g} / \mathrm{ml}$ or less had a longer survival compared with those having elevated IAP levels. Additionally, in the low stage patients, the IAP level decreased significantly after radical nephrectomy compared with that at diagnosis. Patients with the IAP levels of $500 \mu \mathrm{g} / \mathrm{ml}$ or less after nephrectomy also had a longer survival than those with the levels over $500 \mu \mathrm{g} / \mathrm{ml}$.

Based on these results, it was concluded that IAP may be auseful marker for RCC, although it appears valuable for assessing the prognosis than for diagnosis. A more accurate assessment of the prognosis of RCC was possible using a combination of the IAP value and clinical stage.

Ann Cancer Res Ther 3 (1):17 21, 1994 / Received 26 Feb 1994, Accepted 22 Mar 1994

Key words : IAP, RCC, Tumor maker

Although much progress has been made in identified tumor cell surface markers, no tumor-specific markers have yet been established for renal cell carcinoma (RCC). Immunosuppressive acidic protein (IAP), a type $\alpha_{1}$-acid glycoprotein, was one of the first immunosuppressive substances isolated from ascitic fluid and the serum of mice with Ehrlich ascites cancer ${ }^{1,2)}$. It has been reported that serum IAP levels are high in patients with acvanced gastric, colon, gynecologic, and urogenital cancers including RCC, although the pathophysiological role of this protein remains unclear ${ }^{1,3-8)}$.

The present study investigated the clinical usefulness of IAP as a diagnostic or follow-up marker for RCC.

\section{Patients and methods}

Serum IAP levels were evaluated in 68 patients ( 16 women and 52 men) with histologicaly confirmation of RCC between October 1984 and December 1992. The patients ranged in age from 38 to 87 years (mean : 68 years). As a control, IAP levels were also evaluated in 30 healthy adults aged 40 to 68 years (mean : 65 years). The patients were staged according to Robson's

\footnotetext{
- Department of Urology, Iwata Medical University School of Medicine, Morioka 020, Japan

Correspondence to : Tomoaki Fujioka, Department of Urology, Iwate Medical University School of Medicine, 19-1, Uchimaru, Moriok a 020, Japan (Telephone : 0196-51-5111, FAX : 0196-23-1527)
}

classification ${ }^{10)}$, and were divided into two groups, ie., a low stage group (stages I and II) and a high stage group (stages III and IV).

Serum IAP levels were assayed by the single radial immunodiffusion method using an agarose plate containing anti-IAP goat serum (Sanko Pure Chemical Ind., Tokyo). The assay had a cut-off level of $500 \mu \mathrm{g}$ per $1 \mathrm{ml}$ of serum ${ }^{6 \sim 7)}$. All values are expressed as the mean \pm standard deviation (SD). Data were analyzed by the generalized Wilcoxon test using Fisher statistical software. Differences in survival were analyzed according to the Kaplan-Meier method using the same software.

\section{Results}

Serum IAP levels of the,patients and controls.

The IAP levels of the RCC patients at diagnosis were significantly higher than those of healthy controls $(\mathrm{p}<0$. $01)$. The mean IAP value was $707.6 \pm 281.3 \mu \mathrm{g} / \mathrm{ml}$ in the RCC patients and $426.5 \pm 99.2 \mu \mathrm{g} / \mathrm{ml}$ in the controls $(\mathrm{p}<0.01)$ (Fig. 1 ).

When IAP levels of $500 \mu \mathrm{g} / \mathrm{ml}$ or less were defined as normal and those higher were difined as positive, IAP was positive in 43 of the $68 \mathrm{RCC}$ patients and 5 of the 30 controls and there was a significant difference of the positivity rate between the two groups $(p<0.01)$. 


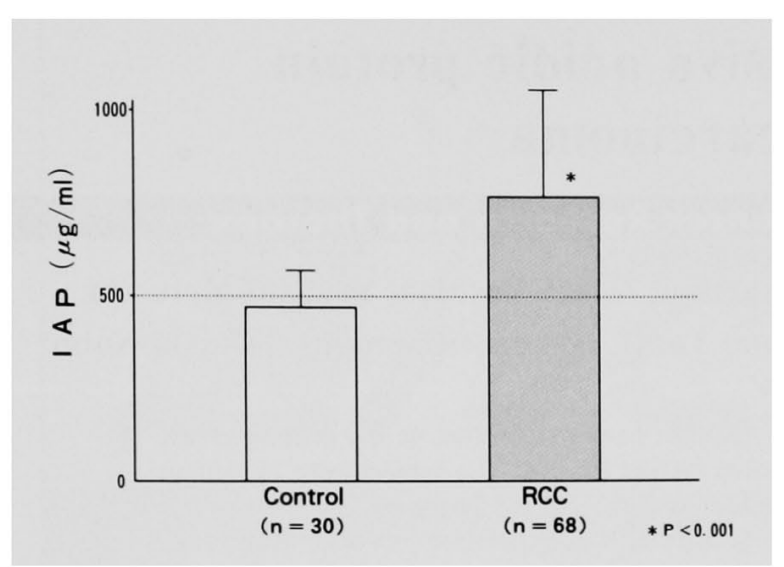

Fig. 1 Serum IAP levels in the patients with renal cell carcinoma and the controls

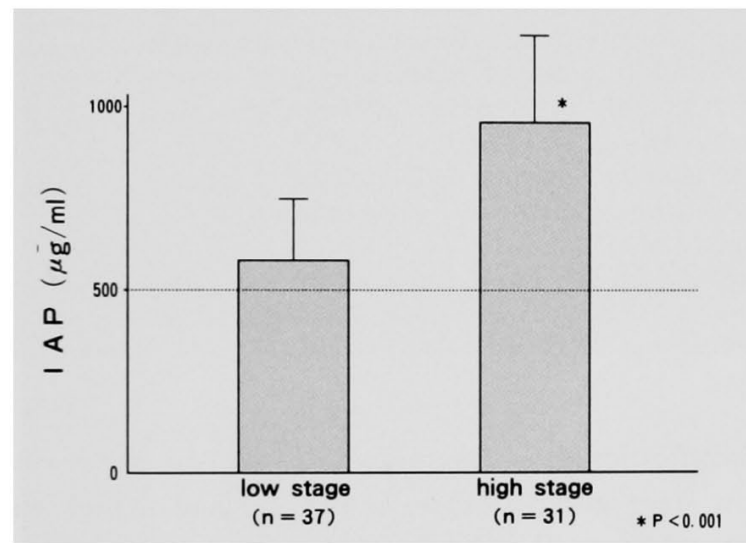

Fig.2 Serum IAP levels in the patients with low and high stage renal cell carcinoma

\section{Relationship between IAP and clinical stage.}

The serum IAP level at diagnosis was $517.7 \pm 72.1$ $\mu \mathrm{g} / \mathrm{ml}$ in the low stage RCC group and $936.8 \pm 120.2$ $\mu \mathrm{g} / \mathrm{ml}$ in the high stage group ( $\mathrm{p}<0.01$ ) (Fig.2).

IAP was positive in 13 out of 37 low stage patients and in 26 out of 31 high stage patients. There was a significant difference of the positivity rate between the two groups $(p<0.01)$.

\section{Relationship between IAP levels and the prognosis}

The patients were divided into the following three groups according to their IAP levels : $\leqq 500 \mu \mathrm{g} / \mathrm{ml}$ (normal group), $500<\leqq 1,000 \mu \mathrm{g} / \mathrm{ml}$ (slightly elevated group), and $>1,000 \mu \mathrm{g} / \mathrm{ml}$ (elevated group). IAP levels at the time of diagnosis were evaluated first. The normal group had a significantly better survival than the slightly elevated and elevated groups ( $p<0.01$ for both groups). Additionally, the survival rate of the slightly elevated group was also significantly better than that of the elevated group $(p<0.05)$ (Fig.3).

In the high stage $\mathrm{RCC}$ patients, the survival rate of the

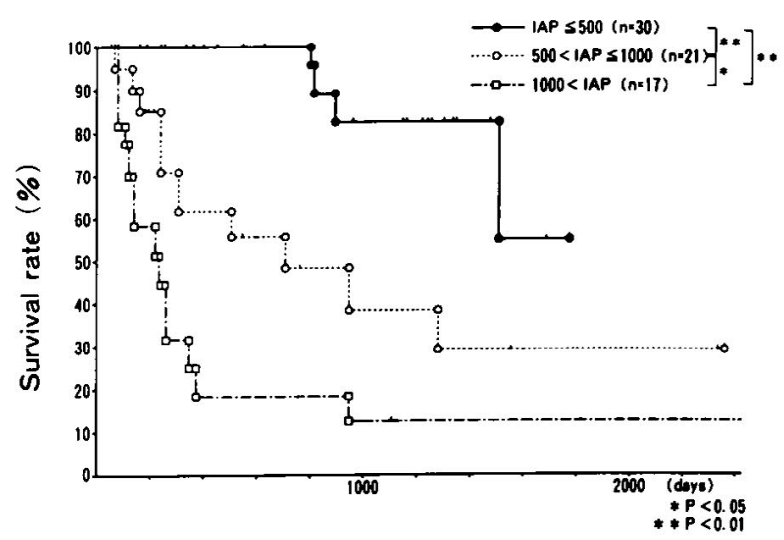

Fig.3 Relationship between the serum IAP level at diagnosis and the prognosis of renal cell carcinoma

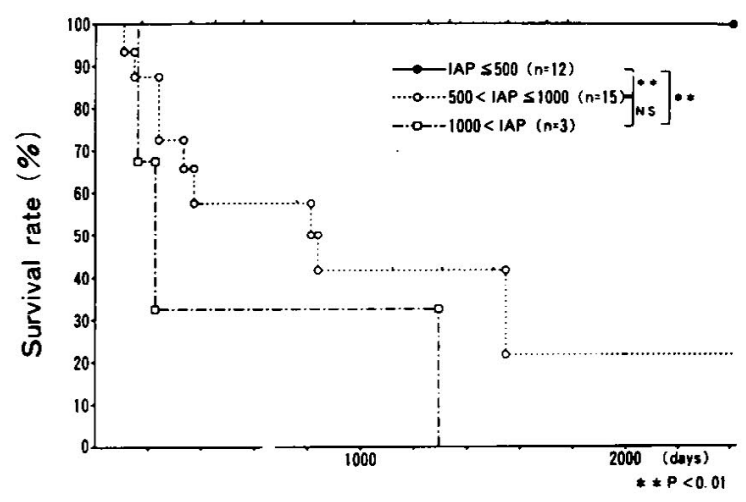

Fig.4 Relationship between the serum IAP level at diagnosis and the prognosis of high stage renal cell carcinoma

normal group was significantly better than that of the slightly elevated or elevated groups $(p<0.01$ for both groups), while there was no difference in survival between the slightly elevated and elevated groups (Fig. 4). In the low stage patients, the survival rate of the elevated group was significantly worse than that of the slightly elabated or normal groups $(\mathrm{p}<00.1)$ (Fig.5).

The relationship between IAP level at 2 months after radical nephrectomy and the prognosis was also studied, since this was a time when IAP values were no longer affected by the operation. Postoperative changes of the IAP level were evaluated in 15 patients who were IAP positive at diagnosis. A significant decrease of the postoperative level was observed in the low stage patients $(p<0.05)$, although there was no significant change in the high stage patients (Fig.6).

The survival rate of the patients with an IAP level $\leqq$ $500 \mu \mathrm{g} / \mathrm{ml}$ after the operation was significantly better than that of patients with a value over $500 \mu \mathrm{g} / \mathrm{ml}(\mathrm{p}<0$. 01 ), while there was no difference in survival beqteen the slightly elavated and elevated gtoups (Fig.7). 


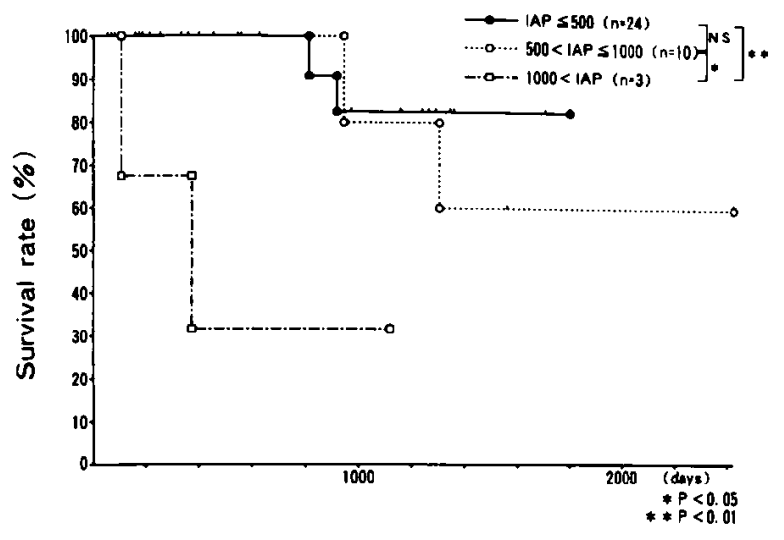

Fig.5 Relationship between the serum IAP level at diagnosis and the prognosis of low stage renal cell carcinoma

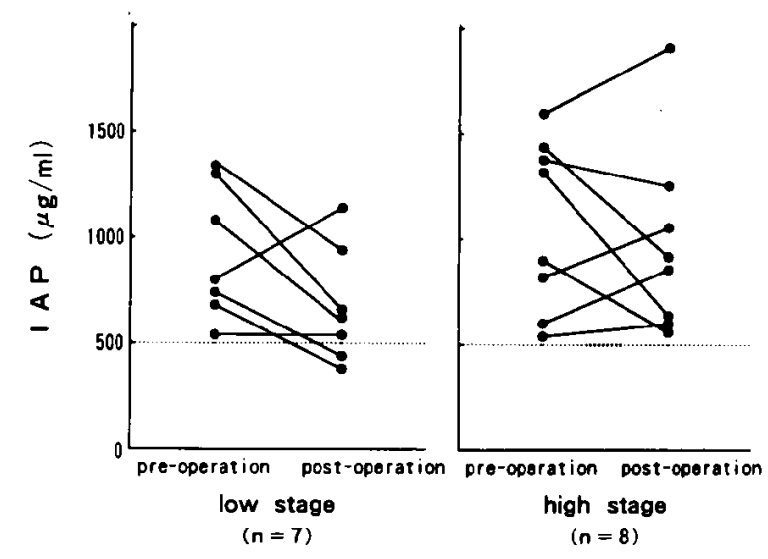

Fig.6 Postoperative changes of serum IAP In the patients with low and high stage renal cell carcinoma

\section{Postoperative changes of $I A P$ in two representative patients.}

Case 1 was a 59 -year-old man with a serum IAP level of $1,055 \mu \mathrm{g} / \mathrm{ml}$ at diagnosis and no evidence of metastatic disease. Right radical nephrectomy was performed under a diagnosis of stage II RCC. The IAP level decreased to below the cut-off value at 2 months after the operation. However, it increased progressivelly over time following the appearance of lung and bone metastases.

Case 2 was a 70 -year-old man with an IAP level of 720 $\mu \mathrm{g} / \mathrm{ml}$ at diagnosis. Right radical nephrectomy was performed under a diagnosis of stage III RCC. The IAP level fell to below the cut-off value at 2 months after surgery and has remained for 4 years with no evidence of recurrence (Fig.8).

\section{Discussion}

Impairment of cellular immunity is common in hosts

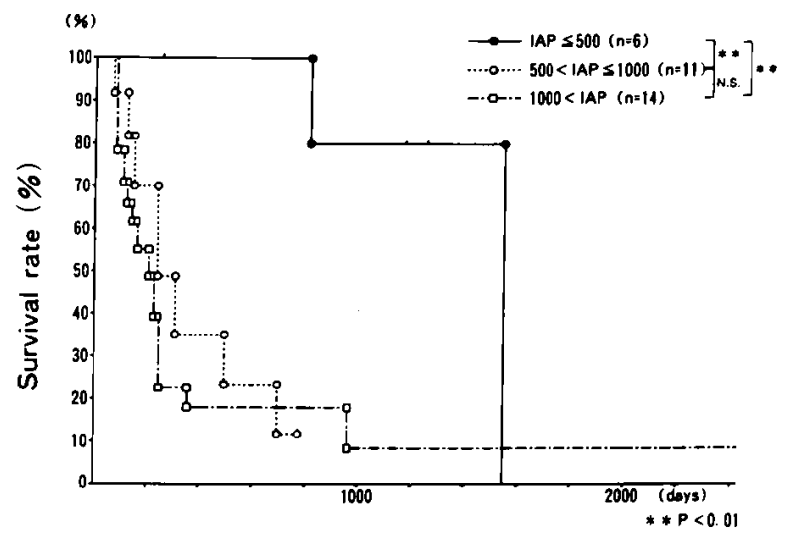

Fig. 7 Relationship between the serum IAP level at 2 months after nephrectomy and the prognosis of renal cell carcinoma

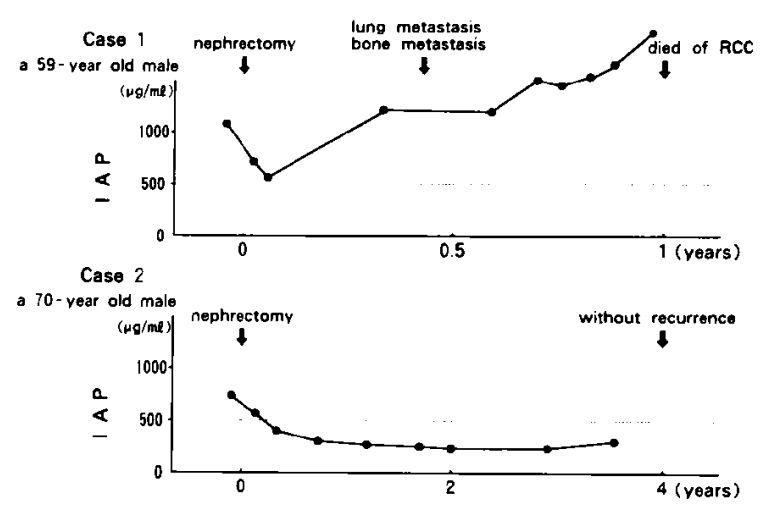

Fig.8 Postoperative changes of serum IAP in two representative patients

with malignant tumors ${ }^{2,11}$. In addition, studies of patients with malignancy reduced cutaneous hypersensitivity to many recall antigens ${ }^{12}$. This immunosuppression has been attributed to the presence of a variety of soluble factors such as IAP, an acidic protein with a molecular weight of 50,000 and isoelectic focusing at $\mathrm{pH}$ 3.0 , which is released by hepatocytes, macrophages, and polymorphonuclear leukocytes ${ }^{13)}$.

It is generally accepted that $500 \mu \mathrm{g} / \mathrm{ml}$ is the upper limit of normal for serum IAP (1). However, Ogoshi and associates defined the upper limit as $558 \mu \mathrm{g} / \mathrm{ml}$, because the mean and standard deviation was $365.6 \pm 100.5 \mu \mathrm{g} /$ $\mathrm{ml}$ in healthy subjects ${ }^{14)}$.

Sakamoto and Nakasato suggested that a cut-off level of $580 \mu \mathrm{g} / \mathrm{ml}$ might be more appropriate than $500 \mu \mathrm{g} / \mathrm{ml}$ for the prognostic evaluation of gastric cancer after curative gasrectomy, and this suggested cut-off level was confirmed by a multicenter study ${ }^{15-16)}$. In the present study, we used $500 \mu \mathrm{g} / \mathrm{ml}$ as upper limit of normal on the basis of previous reports of IAP levels in patients with $\mathrm{RCC}^{7-9)}$. However, further studies might be required to define a more appropriate cut-off value for 
patients with RCC.

To study the usefulness of IAP in screening for RCC, IAP levels were measured in RCC patients at the time of diagnosis and in healthy adults. The IAP level in the RCC patients was significantly higher than that in the controls, and the IAP level in high stage patients was higher than levels in the low stage patients and controls. The IAP positivity rate was $63.2 \%$ in RCC patients and $16.7 \%$ in the controls, respectively. The positivity rate increased with advancing clinical stage, and the rate was $83.9 \%$ in the high stage patients but only $35.1 \%$ in the low stage patients. Thus, the positivity rate of IAP was higher than that of any other RCC markers, including serum basic fetoprotein, tissue polypeptide antigen, serum iron, and haptoglogulin ${ }^{17 \sim 19)}$.

However, it still seems that the usefulness of IAP for detection of RCC is somewhat limited, especially in the case of low stage disease.

Next, we studied the usefulness of serum IAP for monitoring the progress of RCC. The prognosis of patients with raised IAP levels was generally poor. The patients were divided into the low and high stage groups and were also divided into three groups according to their IAP levels. The prognosis of low stage patients with an IAP level over $1,000 \mu \mathrm{g} / \mathrm{ml}$ was quite poor. On the other hand, even high stage patients with an IAP levels of $500 \mu \mathrm{g} / \mathrm{ml}$ or less showed longer survival than those with levels over $500 \mu \mathrm{g} / \mathrm{ml}$. Although tumor stage is an important prognostic factor, the correlation between stage and prognosis is not always so high ${ }^{20,21)}$. Our results indicate that a more accurate assessment of prognosis is possible using a combination of the IAP level and the clinical stage.

The early detection of tumor recurrence is of great clinical importance. It has heen reported that IAP levels were increased in patients with recurrent $\mathrm{RCC}$. In our patients with low stage RCC, the IAP level decreased significantly after nephrectomy. However, the changes of IAP in the high stage group were not uniform. The patients with IAP levels of $500 \mu \mathrm{g} / \mathrm{ml}$ or less at 2 months after surgery had a much better prognosis than the patients with postoperative IAP level over $500 \mu \mathrm{g} / \mathrm{ml}$. Our study of the postoperative changes in IAP suggested that it could be used to indicate the presence of recurrence or metastasis. However, IAP production is also stimulated by various inflammatory conditions and the level of this acute phase reactant is effected by surgery, infection and collagen diseases ${ }^{13,22)}$.

In conclusion, srum IAP level can be used as a prognostic marker for RCC, and also provides a tool for the early detection of recurrence or metastasis.

\section{References}

1) Ishiba N, Tamura K, Shibata $Y$, : The characterization of immunosuppressive acid protein (IAP) and its diagnostic evaluation. Igakunoayumi, $115: 423-433,1980$.

2) Tamura $K$, Shibata $Y$, Matsuda $Y$, Ishida $N$, : Isolation and characterization of an immunosuppressive acidec protein from ascitic fluid of cancer patients. Cancer Res, 41 : 32443252,1981 .

3) Ogoshi K, Miyagi M, Iwata K, Kondo Y, Tajima T, Mitomi $\mathrm{T}$, : Splenectomy, immunosuppressive acid protein and postoperative immunothrrapy in gastric patients with total or proximal gastrectomy : a multivariate analysis. Ann Cancer Res Ther, $1: 61-66,1992$.

4) Sawada M, Okudaira Y, Matsui $Y$, Shimizu Y, : Immunosuppressive acid protein in patients with gynecogogical cancer. Cancer, 54 : 652-656, 1984.

5) Yamamura $T$, Aoizasa K. Tsujimura M, Yoshikawa $K$, Sawada M : Immunosuppressive acidic protein in true histiocytic lymphoma. Cancer, $60: 38-41,1987$.

6) Miki $T$, Saiki S, Kinouchi T, Kuroda M, Kiyohara H, Usami $\mathrm{M}$, Sawada M, Kotake, T : Immunosuppressive acidic protein in patients with testicular cancer. J Urol, $137: 48-52,1987$.

7) Iizumi $T$, Yazaki $T$, Kanoh $S$, Koiso $K$, Inage $H$, Koyama $A$, Tojo S : Circulating immune complexes and immunosuppressive acidic proteinin patients with renal cell carcinoma. J Urol, 134 : 1097-1100, 1985.

8) Ueda $T$ : Serum immunosuppressive acidic protein in renal cell carcinoma. Urol Res, 14 : 101-103, 1986.

9) Igarashi T, Murakami S, Isaka S, Okano T, Shimazaki J, Matsuzaki $O$ : Serum immunosuppressive acidic protein as a tumor maker for renal cell carcinoma. Eur Urol, $19: 332-335$, 1991.

10) Robson C J, Churchill B M, Anderson W : The results of radical nephrectomy for renal cell carcinoma. J Urol, 101 : 297.301, 1969.

11) Varesio L. Holden H T : Regulation of lymphocyte activation : macrophage-dependent suppression of T-lymphocyte protein synthesis. J Immunol, 125 : 1694-170, 1980.

12) Hellstom $K$ E, Hellstom I : Lymphocyte-mediated cytotoxicity and blocking serum activity to tumor antigens. Adv. Immunol, $18: 209-277,1974$.

13) Shibata $Y$, Tamura K, Ishida N : Cultured human monocytes, granulocytes and a monoblastoid cell line (THP-1) synthesize and secrete immunosuppressive acidic protein (a type of alpha-1-acid glycoprotein). Microbiol lmmunol,. 28 : 99-111, 1984.

14) Ogoshi H, Kondoh Y, Nakasaki H, Tajima T, Mitomi T : Immunosuppressive acid glycoprotein (IAP) and immunosuppressive substance. Jap J Cancer Clin, 29 : 987-990, 1983.

15) Sakamoto J, Nakazato $H$ : Statistical study of the proper cut-off point of preoperative serum immunosuppressive acid protein (IAP) for prognosis of gastric cancer in patients undergoing curative gastric resection. Biotherapy, $5: 962-964$, 1991.

16) Sakamoto J, Makasato $H$, Ohashi $Y$, Teramukai $S$, Sazi $S$, Tanemura H, Toge T, Kurosu Y, Morita K, Kaibara N, Shimuzu N, Koie H, Orita K, Inokuchi K : Preoperative serum immunosuppressive acidic protein level in the prognosis of gastric cancer. Jpn J Gastroenterol Surg, 24 : 977-984, 1991.

17) Gohji K, Ishii M, Nagata $H$, Matsumoto O, Kamidono S : Serum basic fetoprotein in patients with renal cell carcinoma. Cancer, 65: 1405-1411, 1990

18) Loughlin K R, Gittes R F : Serum iron : a tumor maker in renal carcinoma. Br J Urol, $58: 617-620,1987$

19) Babaian R J, Swanson D A : Serum haptogloblin, a non- 
specific tumor maker for renal cell carcinoma. South Med J, $75:$ 1345-1348, 1982.

20) Siminovich J M, Montie J E, Staffon R A : Prognostic indicators in renal adenocarcinoma. J Urol, $130: 20-23,1983$.

21) Nurmi M J : Prognoxtic factors in renal cell carcinoma. An evaluation of operative findings. Br J Urol, $56: 270-275,1984$.
22) Tsukamoto $T$, Seki $H$, Takase $T$, Sekizawa $T$, Nakamura $S$ : Significant increase in immunosuppressive acidic protein (IAP) in patients with multiple sclerosis and other inflammatory neurological disorders. J Neurol Sci, $75: 353-361,1986$. 
Serum immunosuppressive acidic protein in renal cell carcinoma

p17-21

Tomoaki Fujioka et al.

Ehelich担癌マウスの腹水，および血清より免疫能抑制 物質とし分離されたIAPは，各種腫瘍の非特異的腫瘍? 一カーとして用いられている，今回，督癌において血清 IAP值の有用性について検討したので報告する.

[対象と方法] 督癌と診断された (女：16, 男：52) を对象とし, 40 68歳の健康成人 30 人 をその对象とした。臨床病期は, Robson分類に準じ, stage I 〜 II low stage, stageIII IVをhigh stage とした. 血清 IAPは，IAPプレートを用いたsingle radical immunodiffusion法により測定, $500 \mu \mathrm{g} / \mathrm{ml}$ をcutoff值とした。

統計学的検討は, Fisherのプログラムを使用し, 多群間 の比較はWilcoxonの手法を，また生存率の比較は Kaplan-Meierの手法により行った。

[結果］（1) 腎癌患者と健康成人の血清IAP值： 督癌症例での平均IAP值は, $707.6 \pm 281.3 \mu \mathrm{g} / \mathrm{ml}$ で，对照 群の $426.5 \pm 99.2 \mu \mathrm{g} / \mathrm{ml}$ に比較し，有意な高值を小した $(\mathrm{p}<0.01) .500 \mu \mathrm{g} / \mathrm{ml}$ 以下を正常とすると，陽性例は督癌 患者68症例中 43 例，対照 30 人中 5 人であった $(\mathrm{p}<0.01)$.

(2) 腎癌患者の血清IAP值と臨床病期の関係：Low stage例の平均IAP值は515.1 $\pm 72.1 \mu \mathrm{g} / \mathrm{ml}$ で, high stage例 の936.8 $\pm 120.2 \mu \mathrm{g} / \mathrm{ml}$ に比較し，有意の低值を示し $(\mathrm{p}<$ $0.01)$ ，その陽性例は各々 37症例中13例, 31症例中26例と 両群間に有意の差異を認めた $(\mathrm{p}<0.01)$.

(3) 督癌患者の血清IAP值と予後の関保：督癌患者を，

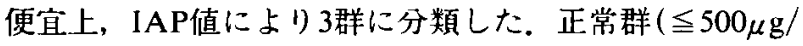
$\mathrm{ml})$ の予後は, やや高值群 $(500 \mu \mathrm{g} / \mathrm{ml}<\leqq 1.000 \mu \mathrm{g} / \mathrm{ml})$ および高値群 $(>1,000 \mu \mathrm{g} / \mathrm{ml})$ に比較し良好で $(\mathrm{p}<0.01)$, やや高值群は高値群に比し良好であった $(p<0.05)$. high stage例において, 正常群は, やや高值群および高値 群に比較し予後良好であり（p<0.01），また， low stage 症例において，高值群は正常群およびやや高值群に比較 し予後不良であった $(p<0.05)$ 。さら代, low stage症例 では，入院時に比較し手術後，有意に減少し $(\mathrm{p}<0.05)$, その正常群では，他の2群に比較し予徯は良好であった $(\mathrm{p}<0.01)$.

[考察] 腎癌患者の血清IAP值は，健康成人に比 較し有意に高値示し，その陽性率は症例全体で $63.2 \%$ 。 対照で16.7\%であった。ささらに, high stageに限ると83.9\%。 となり，従来報告されていたb-FP，TPA，血清鉄，ハフ トグロブリンなどの陽性率より高率ではあるが，堅癌ス クリーニングにおける診断マーカー上しての役割, 特に low stage例においては，限られたものであると考えられ た.

一方，予徯上血清IAP值の関係では， low stage弪例で もIAP $1,000 \mu \mathrm{g} / \mathrm{d} I$ 以上の症例では子後不良であり，また high stage症例でも500 $\mathrm{g} / \mathrm{dl}$ では予後が良好であった. ま た, IAP値の変動は, 臨床経過をよく反映し、術後IAP正 常群では長期生存が期待さ㣗た。
以上より，IAPは子後マーカーであり，臨床病期診断を 併用に上りその有用性は増すと考えられた。

Secretory carcinoma of the breast diagnosed by aspiration biopsy cytology : report of a case $\quad \rho 23 \sim 25$

Tatsuro Makino et al.

乳腺の分泌癌は別名若年性癌ともよばれ，乳癌取扱い 規約にも記されているが，まだその報告は非常にまれで ある。今回筆者らは，穿刺吸引細胞㟝にて特徴的な所見 を呈した成人の乳腺分泌癌を経験したので報告する。

症例は55歳女性で，右乳腺腫瘤を主訴に来院した，触 猃では右乳房BED領域に $1.5 \mathrm{~cm}$ 大の弾性硬，境界明暸で 可動良好な腫瘤を触知したが，皮膚変化は認めず，腋窩 リンハ節も触知しなかった。超音波検査では，腫瘤触知 部に一致して境界鋭，不整型で内部エコーはほほ均一な 低エコ一像を認めた。マンンモグラフィーでは，触診と同 し部位に, 径 $1.7 \mathrm{~cm} の$ 辺縁やや不明瞙な円形腫瘤㓌影を認 めたが，微細石灰化像は明らかではなかった，以上の所 見より嗮癌を疑い，穿刺細胞診を行った結果，Class Vで 右乳癌 (T1 NOM0) と診断し, 非定型乳房切除術を施行 した。

細胞診所見では，核小体の目立つ核を有する細胞の重 積ないしシート状の細胞集塊がみられた。細胞質は豊富 で淡く空胞や粘液を有しており，核は三日月型で偏在し ているものも認められた。これらの細胞集塊はあたかも “ぶン゙うの房”様であった。

組織所見では，大小不同の管肱を形成し，管腔队と細 胞質にPAS, Alcian-blue陽性の分泌物を認めた。また， 腫瘍は間質に富むscirrhosな像を呈し、一部で乳腺外脂肪 組織への浸潤を認めた。以上の所見より乳腺分泌癌上診 断した.

なお，腫瘍組織内ER，PgRは々もに陰性であった。術 後経過は順調で, 現在再発の兆候はない。

分泌癌は、1966年にMcDivitらが、腫瘍細胞が著名な分 泌像を示し，PAS陽性物質が細胞内，腺房梯腔内にみら 机る組織学的特徽を有する3藏から15藏の7例の若年性乳 癌を最初報告した。しかし，1980年にTavassoliらは，成 人においても同様な組織像を呈する乳癌を提示し，若年 者のみにみら机るものではないことを報告した，筆者ら か調べ得な限りでは、本邦では14例の報告があるが，穿 刺吸引細胞診について述べた報告はほとんどみあたらな い. Shinagawaらは最近, 分泌癌の穿刺吸引細胞診におい て, 本症例においても認如札た“ぶどうの房”様の細 胞診所見が特徴的であることを述へてている。

本疾患の予後に関しては，他の乳癌より良好上いう報 告もあるが、本那報告14例についてみてみると，420に ンパ節転移が認められており，今後症例を重ねて検討し ていく必要性があると思われる。 